\title{
Menembus Formalisme Organisasi: Mencermati Tradisi Volunterisme di PM Gontor 7 Putera Sulawesi Tenggara
}

\author{
Badarwan Badarwan \\ Fakultas Tarbiyah dan Ilmu Keguruan, Institut Agama Islam Negeri Kendari \\ Email: badarwan.kdi@gmail.com \\ Syahrul Syahrul \\ Fakultas Tarbiyah dan Ilmu Keguruan, Institut Agama Islam Negeri Kendari \\ Email: syahrul@iainkendari.ac.id
}

\begin{abstract}
This study aims to examine the tradition of volunteerism in Pondok Modern Gontor 7 Putera Southeast Sulawesi, which includes fundamental values developed in building the culture of volunteerism and Pondok Modern Gontor 7 Putera efforts to encourage his citizens to produce the best performance. The research method used is a qualitative descriptive method. Data collection is done through interviews, observations, and documentation. Data were analyzed through the stages of reduction, display, and verification. Data validity is tested through member check, triangulation, extended observation, and increased perseverance. The results of this study indicate that voluntary behaviour is an application of the values of the five souls which are sincerity, simplicity, independence, ukhuwah Islamiyah, freedom, which is the basis in carrying out self-service and self-giving attitude. In improving performance, leaders motivate implementing the concept of five souls as the primary reference in carrying out their duties and responsibilities, including in the application of management functions.
\end{abstract}

Keywords: organizational formalism, voluntary tradition, pesantren

\begin{abstract}
Abstrak
Penelitian ini bertujuan untuk mengkaji tradisi volunterisme di Pondok Modern Gontor 7 Putra Sulawesi Tenggara yang mencakup nilai-nilai dasar yang dikembangkan dalam membangun tradisi volunterisme dan upaya Pondok Modern Gontor 7 putra mendorong warganya untuk menghasilkan kinerja terbaik. Metode penelitian yang digunakan adalah metode kualitatif-deskriptif. Pengumpulan data dilakukan melalui wawancara, observasi, dan dokumentasi. Data dianalisis melalui tahap reduksi, display, dan verifikasi. Keabsahan data diuji melalui member check, trianggulasi, perpanjangan pengamatan, dan peningkatan ketekunan. Hasil penelitian ini menunjukkan bahwa perilaku sukarela merupakan terapan dari nilai-nilai panca jiwa yakni keikhlasan, kesederhanaan, kemandirian, ukhuwah Islamiyah, kebebasan, yang menjadi dasar dalam melaksanakan pengabdian dan sikap mewakafkan diri. Dalam meningkatkan kinerja, pimpinan memberikan motivasi melalui pengimplementasian konsep panca jiwa sebagai rujukan utama dalam menjalankan tugas dan tanggungjawab, termasuk dalam penerapan fungsi-fungsi manajemen.
\end{abstract}

Kata kunci: formalisme organisasi, tradisi sukarela, pesantren

\section{A. Pendahuluan}

Pesantren yang telah berusia ratusan tahun, memiliki berbagai keunikan untuk dipelajari. Ketika pendidikan, terutama di zaman penjajahan, hanya identik dengan trend perkotaan, yang hanya dapat dijangkau oleh kaum bangsawan-saudagar-penjajah, maka pesantren hadir sebagai antitesa terhadap pendidikan yang memberi akses pada semua kalangan, tanpa melihat strata sosial, untuk merasakan pendidikan. Kesadaran eksistensial masyarakat terbangun dari sini, yaitu sebuah kesadaran tentang pentingnya menjadi manusia bermartabat dalam suatu negara merdeka. Perubahan berbagai variabel lingkungan, mengakibatkan pesantren terbiasa bergelut dalam perkembangan globalisasi, dalam ritme yang lambat maupun cepat. Disini terlihat dengan pembelahan tradisi pesantren menjadi "Salaf dan Khalaf", yaitu suatu bentuk respon lembaga yang memilih bertahan atau menerima 
perubahan secara selektif. Meskipun di kemudian hari, batasan salaf dan khalaf semakin tipis, yang berarti bahwa pesantren tidak benar-benar menutup diri terhadap perkembangan, bahkan menganggap kemajuan adalah keharusan ${ }^{1}$.

Pengalaman ratusan tahun menyebabkan Pondok Modern Gontor (selanjutnya disebut PM Gontor) menjadi pesantren yang sangat kokoh secara kelembagaan bahkan menjadi korporasi pesantren terbesar di Indonesia. Fenomena terbaru adalah kesepakatan pengelola menyerahkan PM Gontor sebagai milik umat. Sehingga pengelolaannya berubah secara drastis, dari pengasuh ke Badan Wakaf yang beranggotakan 15 orang. Badan wakaf ini berada di puncak manajemen pondok, membawahi pimpinan pondok, fenomena di atas adalah sikap suka rela yang ditunjukkan oleh pengurus PM Gontor dalam mengabdi kepada kemanusiaan. Sangat manusiawi jika seseorang mempertahankan sesuatu yang telah diperjuangkan dengan keringat dan darah dalam rentang waktu sangat panjang. Tetapi PM Gontor menunjukkan praktik berbeda dengan menyerahkan lembaga tersebut sebagai milik umat Islam ${ }^{2}$. Bahwa substansi pengabdian kepada kemanusiaan tidak dapat dihalangi oleh bingkai organisasi yang formalistik dan mengungkung. Hal ini mendasari semangat penyelidikan lebih lanjut di PM Gontor 7 Putra Sulawesi Tenggara.

Fenomena demikian berlangsung sejak lama sehingga sudah menjadi komitmen kelembagaan secara menyeluruh dalam mengembangkan dan memajukkan PM Gontor. Sebagai wadah untuk menyelami pengetahuan keagamaan secara mendalam guna menghadapi perkembangan dan kemajuan zaman yang semakin modern, perilaku suka rela merupakan suatu tuntutan bagi setiap individu, yang telah mewakafkan diri untuk melakukan pengabdian secara utuh pada lembaga pendidikan. Sikap suka rela juga mampu mengokohkan kekuatan keorganisasian dalam mengembangkan kemajuan ilmu pengetahuan. Dengan sikap demikian PM Gontor mampu bertahan dari segala bentuk perkembangan serta kemajuan ilmu pengetahuan karena kemampuan serta sikap yang telah terbangun secara kuat, yang menjadi dasar utama atas eksistensi lembaga pendidikan yang berbasis dakwah. Pendekatan dinamis dalam keorganisasian menyatakan bahwa organisasi diibaratkan sebagai makhluk hidup yang dapat berkembang, tetapi dapat pula mengalami kematian ${ }^{3}$.

Pesantren lebih cenderung dikategorikan dalam organisasi sosial yang berfungsi perubahan perilaku manusia. Hal ini disebabkan kebutuhan mereka dalam memecahkan persoalanpersoalan bersama, terutama dalam upaya itu adalah memberi kepuasan dalam bekerja, baik dari segi imbalan, penghargaan, pemberdayaan, dan promosi ${ }^{4}$. Kepuasan kerja menyebabkan kesediaan bekerja lebih, bahkan melampaui tanggung jawab formalnya ${ }^{5}$. Kepuasan kerja sebagai sikap positif atau negatif yang dilakukan individual terhadap pekerjaan mereka ${ }^{6}$. Militansi kuat tersebut secara konseptual dikenal sebagai organizational citizenship behavior disingkat OCB, yaitu perilaku pilihan di luar kewajiban formal seorang anggota organisasi tetapi mendukung berfungsinya organisasi secara efektif ${ }^{7}$. OCB terwujud dalam perilaku sukarela, inisiatif pribadi, perilaku ekstra peran, melibihi harapan, yang tidak berkaitan

\footnotetext{
${ }^{1}$ Syahrul, Syahrul. "Strategi Pengembangan Lembaga Pendidikan: Menggali Spirit PM Gontor 7 Putera, Sulawesi Tenggara." Shautut Tarbiyah 24, no. 2 (2018): 334-360.

${ }^{2}$ WARDUN: Warta Duni Pondok Modern Darussalam Gontor Volume 68, Sya'ban 1436 H

${ }^{3}$ Lihat Handoko, T. Hani, Manajemen, Edisi 2, Cetakan Kedelapan belas (Yogyakarta: BPFE UGM,

2003)

${ }^{4}$ Robbins, Stephen P. Organization Theory: Structures, Designs, And Applications, 3/e. Pearson Education India, 1990.

${ }^{5}$ Waspodo, Agung AWS, and Lussy Minadaniati. "Pengaruh Kepuasan Kerja dan Iklim Organisasi Terhadap Organizational Citizenship Behavior (OCB) Karyawan pada PT. Trubus Swadaya Depok." JRMSIJurnal Riset Manajemen Sains Indonesia 3, no. 1 (2012): 1-16.

${ }^{6}$ Wibowo, S. E., and M. Phil. "Manajemen kinerja." Raja Grafindo Persada, Jakarta (2007).

2013.

${ }^{7}$ Robbins, Stephen P., and Timothy A. Judge. Organizational behavior. pearson education Limited,
} 
dengan imbalan atau ganjaran. Sebuah peran yang berjalan secara alami, melekat dalam diri, diarahkan atau tidak, demi keuntungan dan sebesar-besarnya manfaat organisasi ${ }^{8}$.

Ada lima dimensi utama dari Organizational Citizenship Behavior, yaitu: Altruism, yang dapat dimaknai sebagai kemauan membantu tanpa paksaan dalam kegiatan-kegiatan organisasi. Civic Virtue, yang berarti keterlibatan secara sukarela memberi dukungan dalam menjalankan fungsi-fungsi organisasi. Conscinetiousness, memberikan kinerja melebihi standar minimum. Courtesy, perilaku empati dan kepekaan tinggi sehingga tergerak meringankan beban orang lain. Sportmanship, kekuatan bertahan dalam kondisi organisasi yang kurang menguntungkan ${ }^{9}$.

Proses membangun hingga terbentuk militansi anggota organisasi haruslah ditunjang oleh nilai-nilai dasar (espoused values), yaitu sebuah kerangka etik, norma, keyakinan tentang eksistensi organisasi. Nilai-nilai dasar kemudian dikembangkan dalam bentuk asumsi-asumsi dasar (basic assumptions), sebagai argumentasi logis atas pertanyaan tentang nilai-nilai tersebut. Terakhir adalah terwujudnya perilaku yang mencerminkan nilai-nilai dan asumsi dasar (artefacts) ${ }^{10}$. Dengan demikian, tradisi voluntarisme atau sikap kesuka relaan menjadi ekstra peran sangat berhubungan dengan bangunan budaya sebuah organisasi yang menghadapi berbagai tantangan kemajuan.

\section{B. Metode}

Dalam rangka menjawab permasalahan, penelitian ini menggunakan pendekatan kualitatif dengan metode deskriptif. Dengan pendekatan ini peneliti melakukan pencarian informasi dalam kondisi alamiah, yang selanjutnya dikaji berdasarkan teori-teori relevan ${ }^{11}$. Realitas yang coba didalami adalah tradisi voluntarisme di Pondok Modern (selanjutnya disebut PM) Gontor 7 Putra Riyadhatul Mujahidin Sulawesi Tenggara.

Penelitian ini menghasilkan data primer dan sekunder, sehingga sumbernya pun dapat berupa sumber primer maupun sekunder. Data dari sumber primer diperoleh dari Kiai, Pengasuh, Ustadz, dan Santri PM Gontor 7 Putra Sulawesi Tenggara. Sedangkan data dari sumber sekunder diperoleh dari dokumen pondok, majalah, jurnal, dan sebagainya. Sejalan dengan tradisi penelitian kualitatif, maka peneliti menentukan satu informan kunci yakni Kiai, yang dalam asumsi peneliti dalam menjadi titik masuk untuk mendapatkan informasi yang lebih luas.

Proses pencarian informasi penelitian ini melibatkan peneliti sebagai instrumen kunci ${ }^{12}$, dengan menggunakan teknik wawancara mendalam (indepth interview), pengamatan terlibat (participant observation), dan studi dokumen. Proses wawancara menggunakan tape recorder dan buku catatan untuk mendapatkan data terkait nilai-nilai dasar yang ditanamkan di PM Gontor 7 Putra Sulawesi Tenggara. Sedangkan pengamatan dilakukan untuk memahami proses membangun iklmi empati, keterbukaan, dan kinerja terbaik. Adapun studi dokumentasi dilakukan dengan membaca majalah Wardun, jurnal ilmiah, hasil penelitian, maupun dokumen pada website PM Gontor.

Untuk menemukan makna dari data hasil penelitian, dilakukanlah analisis data dengan menggunakan teknik dari Miles dan Huberman, yang meliputi tahap: pengumpulan data, reduksi data, penyajian data, dan verifikasi ataupun penarikan kesimpulan ${ }^{13}$. Setelah data dikumpulkan, maka dilakukan pemilahan, klasifikasi, dan kategorisasi sehingga ditemukan

\footnotetext{
${ }^{8}$ Waspodo, Agung AWS, and Lussy Minadaniati. "Pengaruh Kepuasan Kerja dan Iklim Organisasi Terhadap Organizational Citizenship Behavior (OCB) Karyawan pada PT. Trubus Swadaya Depok." JRMSIJurnal Riset Manajemen Sains Indonesia 3, no. 1 (2012): 1-16.

${ }^{9}$ Badarwan, Badarwan. "Perilaku Sukarela di Pesantren: Karakter Langka di tengah Pusaran Pragmatisme SDM Lembaga Pendidikan." Shautut Tarbiyah 24, no. 1 (2018): 19-36.

${ }^{10}$ Schein, Edgar H. Organizational culture and leadership. Vol. 2. John Wiley \& Sons, 2010.

${ }^{11}$ Lihat Burhan Bungin, Metode Penelitian Kualitatif (Jakarta: Prenada Kencana, 2004).

${ }^{12}$ Lihat Sugiono, Memahami Penelitian Kualitatif (Bandung: Alfabeta, 2003).

${ }^{13}$ Miles, Matthew B. \& Huberman, A. Micahael, Analisis Data Kualitatif: Buku Sumber tentang Metode-Metode Baru, Penerjemah: Tjetjep Rohendi Rohidi, Cetakan Pertama (Jakarta: UI Press, 1992)
} 
polanya. Selanjutnya data disajikan dalam bentuk narasi hingga menampakkan alur temuan. Terakhir adalah melakukan verifikasi atas sajian data untuk mendapatkan kesimpulan akhir yang kuat.

Untuk memberi jaminan bahwa data yang terkumpul sesuai dengan kenyataan pada situasi sosial, maka peneliti menempuh beberapa cara seperti: member check, trianggulasi, perpanjangan pengamatan, dan peningkatan ketekunan. Member check dilakukan dengan cara memberi kesempatan kepada informan untuk membaca narasi yang telah disusun, untuk memastikan kesesuaian maksud informan dengan narasi. Trianggulasi dilakukan untuk memastikan kecocokan data dari berdasarkan sumber, teknik, maupun waktunya. Perpanjangan pengamatan dilakukan untuk memastikan bahwa tidak ada lagi informasi baru yang terlewatkan oleh peneliti. Sedangkan peningkatan ketekunan dilakukan cara membaca secara berulang-ulang sajian data sehingga konsistensinya terjaga.

\section{Hasil Penelitian}

\section{C1. Nilai-nilai dasar dalam membangun tradisi volunterisme}

Pada perkembangan kelembagaan yang memacu keharusan bagi setiap individu untuk menciptakan suatu perubahan sebagai identitas atau ciri khas yang dimiliki, sangat diperlukan perilaku yang menanamkan nilai tersendiri sebagai acuan terciptanya lembaga pendidikan yang mampu berdaya saing. Kondisi demikian mengharuskan bagi PM Gontor 7 putra untuk tetap konsisten pada pusaran kemajuan dan perkembangan ilmu pengetahuan, hal ini dilakukan dengan melalui peningkatan sumber daya manusia secara berkelanjutan guna menjawab kebutuhan akan daya saing, sebagaimana dikemukakan:

"Pada dasarnya setiap individu yang berada dalam lembaga pendidikan PM Gontor dibangun dengan ikatan kekeluargaan sehingga dimanapun berada memiliki ikatan yang kuat sehingga komitmen akan kebersamaan selalu hadir bagi setiap individu tersebut, adapun keinginan untuk mengabdikan diri sebagai sukarelawan pada lembaga tergantung pada sejauhmana keikhlasan bagi setiap individu dan tidak mengharapkan adanya tuntutan secara ekonomis melainkan suatu kesadaran yang penuh akan sebuah pengabdian, walaupun demikian PM Gontor tidak mengabaikan adanya kebutuhan yang mendasar bagi sukarelawan sehingga tanggung jawab lembaga tersebut tetap memenuhi kebutuhan dengan standar lebih manusiawi termasuk peningkatan sumber daya manusia demi menjawab kebutuhan atas kemajuan ilmu pengetahuan dengan kata lain bahwa setiap sukarelawan diberikan peluang untuk meningkatkan kualitas sumber daya manusia dengan melanjutkan jenjang pendidikan pada tingkat selanjutnya dengan beban yang ditanggung oleh PM Gontor atau melalui kerjasama antar lembaga bahkan antar negara tersebut" 14 .

Selanjutnya dikemukakan:

"Dalam pelaksanaan proses pembelajaran pada PM Gontor saat sekarang ini lebih terfokus pada penguasaan ilmu pengetahuan yang berbasis teknologi walaupun diisi lain kami harus memenuhi segala kebutuhan para tenaga sukarelawan yang lebih manusiawi sehingga tidak terjadi diskriminasi dalam pengelolaan lembaga pendidikan, mengingat pondok tersebut merupakan pondok yang mengadopsi secara modern sehingga tidak harus menunggu kebijakan para pendiri lembaga melainkan segala kebutuhan sudah menjadi bagian yang menangani pengelolaan sumber daya yang dimiliki yang dapat menghasilkan pendapat secara ekonomis yang segala pemenuhan kebutuhan yang berada

${ }^{14}$ Ar, Wawancara Dengan Pimpinan Pondok Modern Gontor Putra VI Sulawesi Tenggara. Konawe Selatan, 12 Mei 2018. 
di PM Gontor tidak berasal dari seberapa besar iuran yang disetorkan oleh para santri kepada pihak pengelola". ${ }^{15}$

Senada dengan itu, Fananie menyatakan bahwa pendidikan adalah membentuk menunjukkan jalan kepada anak-anak atau kepada siapa saja yang dapat berjalan dan memilih jalannya sendiri, menurut ajaran Islam yang dinamakan jalan yang benar itu adalah tunduk kepada Allah dan patuh terhadap perintah-perintahnya. ${ }^{16}$

Demikian pula nilai dasar tidak hanya muncul ketika setiap individu telah menyelesaikan tugas pendidikan pada jenjang yang ada melain telah dibentuk sejak awal sehingga kebiasaan untuk mengabdi kepada yang lain telah tertanam pada setiap insan sejak menjadi peserta didik, sehingga nilai sukarelawan terbentuk sejak awal yang kemudian menjadi ukuran dasar seseorang untuk menjadi sukarelawan pada tingkat selanjutnya, sehingga nilai-nilai keikhlasan menjadi dasar utama untuk menjadi sukarelawan. Untuk menjadi sukarelawan tidak akan memberikan pendapat secara ekonomis sesuai dengan standar pendapatan saat sekarang ini, sehingga menjadi sukarelawan hanya membutuhkan pentingnya nilai-nilai panca jiwa untuk diterapkan dalam kehidupan terutama dalam pelaksanaan tugas dalam membentuk sikap dan karakter para santri dan atas dasar keinginan lembaga melainkan suatu pilihan bagi individu tersebut sehingga tidak memiliki unsur paksaan baik secara kelembagaan maupun secara personal akan tetapi suatu kesadaran penuh bagi setiap individu yang mengabdikan diri sebagai sukarelawan, bahkan masyarakat di luar lembaga pun juga diberikan ruang untuk masuk menjadi sukarelawan, kebijakan demikian tidak lahir pada seorang kiai atau pimpinan pondok melainkan atas dasar kerelaan untuk mengembangkan lembaga secara bersama-sama. Pondok Modern Gontor berdiri setelah masa transisi diilhami oleh konsep kepemimpinan TRIMURTI sebagai sosok tokoh teladan yang selalu mengedepankan kepentingan umat dari pada kepentingan pribadi maupun keluarganya, sehingga PM Gontor mampu berdiri kokoh pada setiap sisi masa kehidupan ini. Nilai-nilai dasar yang telah ditanamkan oleh Trimurti tersebut menjadi dasar utama dalam membina konsep keumatan sehingga pada kenyataannya PM Gontor mampu menghadirkan kematangan ilmu pengetahuan bagi setiap individu yang telah bersedia mewakafkan diri pada lembaga pendidikan tersebut, tak terkecuali para pembina dan guru bagi santri di PM Gontor 7 Putera.

Dengan didasari nilai keikhlasan bagi pimpinan pondok, pengasuh/pembina dan guru pada lembaga menjadi suatu spirit untuk mewakafkan diri sebagai sukarelawan sehingga tujuan untuk mengabdikan diri sudah benar-benar menjadi tujuan utama, kerelaan tanpa pamrih untuk memberikan pelayanan dan bimbingan bagi para santri yang merupakan suatu prestasi tersendiri, sebagaimana mengemukakan bahwa: "Nilai-nilai keikhlasan serta kemandirian harus mampu dimiliki oleh setiap pengasuh maupun guru serta para santri, agar menjadi dasar utama dalam menjalankan tugas guna membina, mendidik serta membentuk karakter bagi setiap individu terutama para santri yang dalam kenyataannya masih sangat membutuhkan penyesuaian terhadap lingkungan pendidikan yang baru, mengingat para santri akan sangat mengalami kesulitan terhadap kondisi belajar yang baru, dan bagi sukarelawan dibutuhkan keikhlasan dan kemandirian penuh dalam menjalankan tugas dan tanggungjawab, sebab bagi relawan telah mewakafkan diri untuk memberikan pengabdian bagi lembaga serta umat secara utuh". ${ }^{17}$

\footnotetext{
${ }^{15} \mathrm{Ar}$ Ir, Wawancara Dengan Relawan/Guru pada Pondok Modern Gontor 7 Putera Sulawesi Tenggara. Konawe Selatan 12 Mei 2018.

${ }^{16}$ Muhammad Husen Sanusi, Trimurti: Menelusuri Jejak, Sintesa, dan Genealogi berdirinya Pondok Modern Darussalam Gontor (Bantul: Etifaq Production, 2016), h. 171.

${ }^{17}$ If, Wawancara Dengan Relawan/Guru Pada Pondok Modern Gontor 7 Putera Sulawesi Tenggara. Konawe Selatan, 13 Mei 2018
} 
Nilai-nilai dasar yang menjadi salah acuan untuk menjadi sukarelawan yakni kemampuan seseorang membina serta memberikan pendidikan dengan didasarkan melayani secara ikhlas serta tidak memiliki ketergantungan terhadap orang lain baik dalam menjalankan tugas sebagai relawan maupun sebagai anggota masyarakat dalam konteks perilaku kepesantrenan, nilai-nilai tersebut mampu diterapkan bag setiap individu yang ada, baik sebagai pengasuh maupun sebagai guru bahkan terlebih lagi bagi pimpinan pondok sebagai teladan yang dapat menjadi panutan utama pada Pondok tersebut. Penanaman nilai-nilai fundamental dalam konsep ke'Gontor'an merupakan syarat utama sebagai dasar dalam menjalankan tugas sebagai sukarelawan. Hal ini menunjukkan dinamika pesantren yang progresif, tidak hanya bertahan pada akar sejarahnya, yang concern dalam kajian keagamaan.

Hal ini didasari oleh sisi humanisme yang dalam tradisi pesantren ${ }^{18}$, bahwa persoalan kemanusiaan tidak dapat didekati dari aspek keagamaan semata, tetapi perlu ditopang dari berbagai sudut pandang. Kecenderungan humanistik pesantren tidak jarang dipersepsikan sebagai bentuk sosialisme ${ }^{19}$. Dengan demikian pengabdian secara utuh bagi sukarelawan merupakan suatu keunikan tersendiri karena telah mewakafkan diri untuk mengabdi demi kepentingan umat sehingga ketika seseorang telah mewakafkan diri pada PM Gontor maka mereka tidak lagi berkeinginan untuk mencari tempat lain untuk mengabdi, sehingga konsep mewakafkan diri benar-benar hanya untuk kepentingan umat semata, komitmen demikian merupakan keunikan tersendiri bagi lembaga pendidikan setingkat PM Gontor yang mampu membentuk karakter serta perilaku bagi relawan untuk mengabdikan diri, kerelaan dalam mewakafkan diri untuk mengabdikan sepanjang hayat merupakan pengabdian yang tidak memiliki batas serta tidak dapat dipandang sebagai sesuatu yang sangat sederhana melainkan menjadi suatu yang lebih istimewa.

Kemudian nilai-nilai kemandirian juga merupakan ukuran dasar yang harus dijalankan bagi setiap baik pimpinan pondok, pengasuh maupun guru dalam menjalankan segala aktivitas pada lembaga tersebut, kemandirian adalah merupakan suatu kewajiban sehingga sikap ketergantungan terhadap orang lain dapat dihilangkan, bagi setiap suka relawan tidak dibenarkan baik dalam menjalankan tugas sebagai pembina maupun pembimbing bagi santri diberikan kepada suka relawan lainnya termasuk dalam pemenuhan kebutuhan pribadi tidak diberikan kewenangan agar individu yang lain menjalankannya, sehingga lembaga bagi setiap individu dijalankan secara bertanggung jawab tanpa mengharap belas kasihan atau bantuan orang lain, artinya lembaga Gontor dijalankan atas dasar pemanfaatan sumber daya manusia secara mandiri yang dikembangkan tanpa mengharapkan bantuan orang lain.

Nilai kemandirian ditanamkan secara menyeluruh baik bersifat individual maupun kelembagaan sehingga segala potensi yang dimiliki dikerahkan agar dapat mendapatkan hasil yang memuaskan dan hal tersebut merupakan salah satu dasar utama bagi setiap insan baik sebagai santri maupun sebagai Pimpinan, Pengasuh maupun para guru, sebagaimana dikemukakan:

"Setiap orang yang telah mewakafkan diri pada PM Gontor ini termasuk santri sangat tidak dibenarkan untuk mencari sesuatu tambahan penghasilan atau bantuan kepada orang lain yang memiliki kemampuan secara ekonomi agar memberikan harta atau nafkah kepada orang tertentu yang ada pada PM Gontor, karena PM Gontor didirikan bukan karena uluran tangan atau belas kasihan orang lain, melainkan kemajuan PM Gontor adalah kemandirian dan kegigihan untuk mengembangkan diri adapun jika bantuan yang masuk pada lembaga ini merupakan kerelaan bagi setiap orang yang ingin menginfakkan sebahagian hartanya untuk kepentingan umat tanpa ada ikatan apapun artinya seseorang

\footnotetext{
${ }^{18}$ Ngarifin Sidhiq, Humanisme Pendidikan Pesantren, AL-QALAM 11, no. 2 (2016)

${ }^{19}$ Husnul Amin, Corak Sosialisme Pesantren (Jurnal Pendidikan Islam Vol. X7, No.3 2012/1433)
} 
karena ketulusan dan kerelaan semata, bukan usaha yang dilakukan oleh unsur-unsur yang mengelola lembaga ini." 20

Hal di atas menunjukkan bahwa nilai-nilai kemandirian yang dianut pada PM Gontor merupakan kemampuan memanfaatkan sumber daya yang dimiliki oleh lembaga guna mengembangkan kemajuan ilmu pengetahuan tanpa mengharap belas kasihan dari orang lain sehingga bisa bertahan dalam pusaran kemajuan, melainkan suatu usaha yang sangat gigih untuk maju dan berkembang, nilai kemandirian menjadi salah satu kekuatan utama dalam mengembangkan amanah keorganisasian sehingga terbentuk karakter yang tangguh secara fisik maupun mental dalam menghadapi kemajuan saat sekarang ini. Dalam penelitian juga ditemukan nilai-nilai yang memiliki peran penting dalam membangun karakter serta menjadi kekuatan secara mental bagi seluruh elemen kelembagaan yang ada yakni nilai-nilai Ukhuwah Diniyah, sebagaimana dikemukakan:

"Nilai ukhuwah diniyah yakni ukhuwah Islamiyah artinya membangun kekuatan mental serta dalam memberikan pengetahuan dan keterampilan pada setiap individu didasari terbangunnya hubungan kekeluargaan yang erat sehingga dapat untuk saling memahami dan mengerti atas kekerabatan yang terbangun secara struktural dengan terbangunnya ukhuwah Islamiyah yang mendalam akan mampu membangkitkan semangat kekeluargaan yang kuat sehingga dapat bekerjasama dalam meraih hasil yang diharapkan terutama dalam membentuk keagamaan yang mendasar dan kokoh terutama dalam menghadapi segala perkembangan dan kemajuan zaman saat sekarang ini." 21

Berdasarkan temuan penelitian bahwa ukhuwah Islamiyah merupakan kekuatan yang amat kokoh dalam membentuk dan menciptakan hubungan kekeluargaan yang kuat karena kehidupan pada pondok pesantren tidak pernah lepas hubungan kekerabatan yang kuat sebagai ciri khas yang dimiliki pada setiap pondok sebagai lembaga pendidikan yang berbasis pada pendidikan Islam. Karena kepuasan kerja menyebabkan kesediaan bekerja lebih bahkan melampaui tanggung jawab formalnya ${ }^{22}$. Kepuasan kerja sebagai sikap positif atau negatif yang dilakukan individual terhadap pekerjaan mereka. ${ }^{23}$

Militansi kuat tersebut secara konseptual dikenal sebagai organizational citizenship behavior disingkat OCB, yaitu perilaku pilihan di luar kewajiban formal seorang anggota organisasi tetapi mendukung berfungsinya organisasi secara efektif ${ }^{24}$ sehingga mampu membangun ukhuwah Islamiyah merupakan nilai dasar perilaku pondok pesantren Gontor sebagai unsur yang terpenting dalam membentuk karakter serta perilaku para santri selama mengenyam pendidikan pada pondok tersebut maka dapat diketahui bahwa nilai kebebasan yang dianut oleh setiap individu yang berada pada lembaga pendidikan menjadai dasar untuk mengembangankan bakat serta ilmu pengetahuan yang akan dipelajari dan dikembangakan selama tidak bertentangan nilai dasar yang dianut oleh konsep pendidikan ke'Gontor'an, juga kebebasan menentukkan pilihan setiap individu yang ada di Gontor tidak dapat diintervensi hanya untuk memenuhi keinginan orang lain demi kepentingan dirinya sendirinya, dengan konsep demikian dapat menjadikan seseorang lebih cerdas dalam menentukkan pilihanpilihannya sendiri.

${ }^{20}$ Sf, Wawancara dengan Guru/Relawan Pada Pondok Modern Gontor 7 Putera Sulawesi Tenggara. Konawe Selatan 29 Juli 2018.

${ }^{21}$ Ar, Wawancara dengan Pimpinan Pondok Modern Gontor 7 Putera Sulawesi Tenggara. Konawe Selatan 28 Juli 2018.

${ }^{22}$ Agung AWS. Waspodo, Pengaruh Kepuasan Kerja dan Iklim Organisasi terhadap Organizational Citizenship Behavior (OCB), (Jurnal Riset Manajemen Sains Indonesia JRMSI, Vol. 3, No. 1, 2012).

${ }^{23}$ Wibowo, Manajemen Kinerja (Jakarta, Raja Grafindo Persada, 2007).

${ }^{24}$ Robbin, Stephen P. \& Judge, Timothy A., Organizational Behavior, Fifteenth Edition (USA: Pearson Education Inc, Prentice Hall, 2013). 
Berdasarkan sumber penelitian maka dapat dikemukakan bahwa dalam menanamkan nilai-nilai dasar sukarela dimulai dengan implementasi panca jiwa yakni keikhlasan, kesederhanaan, kemandirian, ukhuwah Islamiyah, kebebasan, dengan panca jiwa inilah menjadi dasar utama untuk mengembangkan dan membesarkan lembaga yang juga menjadi komitmen bersama bagi yang telah mewakafkan diri pada Pesantren Gontor untuk mendidik dan membina setiap insan sebagai bekal kehidupan yang kekal.

\section{C2. Mendorong warganya untuk menghasilkan kinerja}

Pada setiap lembaga atau organisasi akan selalu memiliki orientasi kerja secara maksimal sehingga dapat menghasilkan suatu prestasi atau kinerja yang lebih maksimal, hal ini juga tidak terlepas dari sistem pengelolaan lembaga pada saat ini, sebab jika pengelolaan lembaga tidak dilakukan secara maksimal maka sudah dapat diasumsikan bahwa lembaga tersebut akan mengalami kemunduran bahkan kehancuran pula, seorang pemimpin pada sebuah lembaga atau organisasi yang harus mampu menjalankan mengkoordinasikan serta mengkomunikasikan segala bentuk program-program yang menjadi tujuan utama dalam membangun sebuah lembaga yang memiliki kematangan. Setiap pemimpin juga harus mampu membangkitkan gairah serta motivasi yang kuat agar setiap individu mampu mengembangkan diri dan mampu melaksanakan tugas secara maksimal tanpa memiliki ketergantungan terhadap orang lain sebagaimana Pesantren Gontor terkenal sebagai pesantren modern pertama di Indonesia. Ciri khas pesantren modern berupaya memadukan tradisionalitas dan modernitas pendidikan.

Dalam setiap kegiatan yang akan dilaksanakan selalu mengacu pada program yang telah ditetapkan sebelumnya sehingga setiap individu melaksanakan tugas berdasarkan koridor yang ada untuk menjadi rambu-rambu dalam menjalankan tugas tersebut, setiap individu ditekankan agar lebih fokus pada program yang menjadi prioritas utama dengan mengacu pada aspek kurikulum, fungsi yayasan, aspek kemasyarakatan, sebagaimana dikemukakan:

"Sebagai relawan yang telah mewakafkan diri pada lembaga ini, kami melaksanakan tugas dengan mengacu konsep pengajaran klasikal dengan menyesuaikan kurikulum terpadu dan kami mengabdikan diri tidak melihat seberapa besar apa yang harus kami dapatkan melainkan hanya sebagai pengabdian semata sehingga kami melaksanakan tugas sebagai pengabdian kepada sesama manusia dan menjadi bekal kehidupan di akhirat nanti, kami selalu diberikan motivasi kepada pembina dan pimpinan pondok bahwa dalam kehidupan ini yang terpenting adalah sejauhmana kita hidup mampu berarti bagi kehidupan orang lain dan agama secara khusus, kami siap ditempatkan dimana saja untuk menjalankan tugas pengabdian karena menjadi keharusan bagi kami setelah mewakafkan diri pada lembaga ini". 25

Lebih lanjut dinyatakan:

"Kami harus mampu melaksanakan tugas yang telah kami emban mengingat secara individu kami telah mewakafkan diri untuk melakukan pengabdian secara utuh tanpa mengharapkan sebesar apapun secara ekonomi yang dapat kami peroleh, mengingat iuran yang diserahkan oleh para santri kepada pengelola tidak mampu memenuhi segala kebutuhan para santri, apalagi kebutuhan para pengelola dan para sukarelawan amat sulit untuk terpenuhi sehingga dengan dasar demikian pimpinan selalu menekankan agar pelaksanaan tugas tersebut tidak didasarkan atas ukuran secara ekonomis melainkan atas dasar ketundukan dan kepatuhan kita terhadap Allah swt. sebagai insan yang dapat bermanfaat bagi orang lain". ${ }^{26}$

${ }^{25}$ Yf, Wawancara Dengan Guru/Relawan Pada Pndok Modern Gontor 7 Putera Sulawesi Tenggara. Konawe Selatan, 11 Agustus 2018.

${ }^{26} \mathrm{Rj}$, Wawancara Dengan Guru/Relawan Pada Pndok Modern Gontor 7 Putera Sulawesi Tenggara. Konawe Selatan, 11 Agustus 2018. 
Dengan demikian bahwa pelaksanaan tugas sebagai relawan dalam lembaga ke'Gontor'an perlunya memaknai secara mendalam konsep panca jiwa yang diterapkan sebagai dasar utama dalam melaksanakan tugas sebagai relawan secara maksimal terutama dalam proses belajar mengajar karena sistem pengajaran formal ala klasikal (pengajaran di dalam kelas) dan kurikulum terpadu diadopsi dengan penyesuaian tertentu tanpa menghitung seberapa besar pendapatan yang harus diperoleh melainkan suatu pengabdian yang tulus yang dapat diberikan pada lembaga sekarang ini.

Berdasarkan hasil wawancara diketahui bahwa pelaksanaan tugas tanggung jawab dalam menghasil kinerja yang lebih maksimal dilakukan melalui implementasi nila-nilai panca jiwa sebagai motivasi utama dalam melaksanakan tugas tersebut, sebab setiap sukarelawan sudah mengetahui apa yang menjadi tanggungjawab masing-masing sehingga tidak perlu ada lagi arahan dari pimpinan maupun pembina sehingga sukarelawan menjalankan tugas didasarkan atas kemandirian artinya pemahaman dan implementasi nilainilai panca jiwa sudah dapat menjadi ukuran bagi tercapainya kinerja secara maksimal, namun pimpinan tetap melakukan evaluasi kinerja guna mengetahui secara pasti dalam pelaksanaan tugas tersebut, sebagaimana Kreitner dan Kinicki mengemukakan bahwa sasaran evaluasi dari segi pendekatannya, yang disebutkan sebagai pendekatan terhadap sifat, perilaku, hasil dan kontijensi, sementara Robbins melihat evaluasi kinerja dalam ukuran hasil pekerjaan individu, perilaku dan sikap" 27 dari pendapat tersebut menegaskan kinerja invididu akan diketahui keberhasilannya jika sudah mampu memberikan hasil sesuai tujuan organisasi yang diharapkan, mengingat kinerja seseorang sudah mampu diketahui hasilnya secara keseluruhan.

Dengan demikian maka dapat disimpulkan bahwa dalam pelaksanaan tugas dan tanggungjawab sebagai sukarelawan pihak pimpinan maupun pembina tidak melakukan pengawasan namun dilakukan dengan melalui evaluasi secara keseluruhan atas tugas yang telah dilaksanakan, mengingat tugas dan tanggungjawab yang diberikan pada relawan sudah dapat dipahami dan dilaksanakan secara keseluruhan tanpa memiliki ketergantungan terhadap orang lain atau bahkan tidak mengharapkan bantuan orang lain terkait tugas dan tanggungjawab yang diberikan baik dari program lembaga maupun tugas tambahan dari pimpinan pondok. Informasi mengemukakan:

"Kegiatan yang kami laksanakan bukan saja tentang pelaksanaan kurikulum melainkan tentang pengetahuan dan sikap toleransi bagi para santri sehingga proses pembelajaran tidak hanya berlangsung dalam kelas semata melainkan terjadi pada luar kelas atau kegiatan ekstrakurikuler yang mampu di implementasikan dalam kehidupan sehari-hari bagi setiap santri, mengingat saat sekarang ini para santri membutuhkan pengetahuan tentang pentingnya nilai-nilai toleransi guna menjaga harmonisasi kehidupan ketika sudah berada di luar PM Gontor karena harapan para pendiri adalah bagaimana keluaran atau lulusan Gontor mampu menjadi teladan di tengah masyarakat dan menjadi pencerah secara menyeluruh dalam kehidupan pribadi maupun berkelompok" 28 .

Keterbatasan masa pengajaran di kelas dapat ditangani pondok pesantren dengan adanya banyak waktu luang yang dapat dimanfaatkan para guru untuk melengkapi pengajaran kepada santri. Pola ini sangat mengefisienkan waktu dan membuat pengajaran menjadi efektif. Ditambah lagi dengan arus utama sistem pendidikan di pondok modern yang tidak mengenal dikotomi pendidikan ekstrakulikuler dan intrakulikuler. Keutamaan pendidikan toleransi di pondok modern juga tercermin dari muatan/isi kurikulum yang kentara mengajarkan wawasan santri akan keragaman keyakinan. Dalam kelompok bidang studi Dirasah Islamiyah, sebagai contoh, diajarkan materi khusus Muqaranatal-Adyan (Perbandingan Agama) yang konten

${ }^{27}$ Wibowo, Manajemen Kinerja (Jakarta: Raja Grafindo Persada, 2010), hlm. 351.

${ }^{28}$ Lh, Wawancara Dengan Guru/Relawan Pada Pndok Modern Gontor 7 Putera Sulawesi Tenggara. Konawe Selatan, 12 Agustus 2018. 
luasnya memaparkan sejarah, doktrin, isme, fenomena dan dinamika keagamaan di dunia. Materi ini sangat substansial dalam pendidikan multikulturalisme, karena santri diberi wawasan berbagai perbedaan mendasar keyakinan agama mereka (Islam) dengan agamaagama lain di dunia. Materi ini sangat potensial membangun kesadaran toleransi keragaman keyakinan yang akan para santri temui saat hidup bermasyarakat kelak.

Dalam pendidikan sikap multikulturalistik, pondok modern menerapkan pemberian wawasan rutin melalui visualisasi aneka kultur dan budaya para santrinya. Setiap tahun ajaran baru digelar seremoni besar Khutbatul'Arsy dengan salah satu materi acara berupa pertunjukan aneka kreasi dan kreativitas pelangi budaya semua elemen santri, berdasarkan kategori "konsulat" (kedaerahan). Dalam acara ini dilombakan demontrasi keunikan khazanah dan budaya tempat domisili asal santri. Semua santri diwajibkan terlibat dalam kegiatan ini. Namun terkait dengan pengabdian sebagai sukarelawan terutama dalam meningkatkan kinerja masih memerlukan perhatian secara bersama, artinya bukan hanya pada lembaga melainkan kepada masyarakat terutama orang tua para santri, mengingat kewajiban santri atas iuran yang harus disetorkan secara matematis tidak dapat memenuhi kebutuhan secara mendasar terutama bagi santri itu sendiri.

Berdasarkan hasil penelitian bahwa dalam meningkatkan kinerja para bawahan terutama para sukarelawan tidak hanya berapa besaran pendapatan yang diperoleh atau setoran biaya para santri namun lembaga tidak memperoleh biaya dari santri melainkan dari usaha-usaha yang dimiliki oleh lembaga melalui pengelolaan yayasan sehingga dalam memberikan pembinaan serta pengajaran kepada para santri tidak didasarkan dari aspek ekonomi namun didasarkan pada aspek religius sebagai bentuk pengabdian kepada yang maha kuasa dan tugas sebagai sukarelawan hanya dibutuhkan kesungguhan dalam pengabdian terutama bagi individu yang telah mewakafkan diri pada lembaga secara utuh tanpa melihat berapa besaran atau upah yang akan diterima, karena pada PM Gontor tidak diketahui besaran upah yang diterima oleh para sukarelawan. Hal demikian sudah menjadi peraturan yang diterapkan oleh lembaga untuk menjadi acuan secara keseluruhan dalam melakukan proses pengabdian yang didasarkan oleh keikhlasan secara utuh dan paripurna, sebagaimana OCB terwujud dalam perilaku sukarela, inisiatif pribadi, perilaku ekstra peran, melebihi harapan, yang tidak berkaitan dengan imbalan atau ganjaran. Sebuah peran yang berjalan secara alami, melekat dalam diri, diarahkan atau tidak, demi keuntungan dan sebesar-besarnya manfaat organisasi ${ }^{29}$. Perilaku tersebut mencakup beberapa istilah yang saling terhubung satu sama lain, yakni personal industry, loyal boosterism, individual initiative, dan interpersonal helping ${ }^{30}$. Walaupun secara keorganisasian dibutuhkan pengelolaan lembaga secara profesional sehingga di sisi lain dibutuhkan keterbukaan dalam pengelolaan sehingga dapat diketahui dan diukur tingkat kesejahteraan pada sukarelawan, karena dengan demikian akan mampu meningkatkan kinerja secara menyeluruh dalam memberikan pelayanan terutama pemenuhan kebutuhan para santri demi kemajuan lembaga atau organisasi.

\section{Pembahasan}

Relawan atau Volunteer adalah orang yang melakukan suatu hal dengan sukarela untuk membantu masyarakat yang membutuhkan tanpa pamrih dan mengharapkan imbalan ${ }^{31}$. Clary dan Synder menyatakan bahwa relawan memiliki beberapa fungsi yaitu nilai, pemahaman, peningkatan, karir, sosial dan protektif. Relawan memiliki fungsi dalam

\footnotetext{
${ }^{29}$ Agung AWS Waspodo, Pengaruh Kepuasan Kerja dan Iklim Organisasi terhadap Organizational Citizenship Behavior (OCB) Maret 2015).

${ }^{30}$ Nenet Natasudian Jaya, Meningkatkan Perilaku Ekstra Peran Karyawan (GaneC Swara, Vol. 9 No. 1

${ }^{31}$ Tim Penyusun Kamus Pusat Bahasa. "Kamus Bahasa Indonesia." Jakarta: Pusat Bahasa (2008).
} 
mempercepat terjadinya proses penanggulangan kemiskinan di masyarakat ${ }^{32}$. Sedangkan tugas relawan adalah membantu orang-orang lain (warga masyarakat), dan menjalankan misi sebagai agen perubahan/pembaharuan di masyarakat. Kerelawanan telah menjadi bagian dari pengalaman kemanusiaan. Menjadi relawan adalah pilihan untuk berbuat dengan sikap tanggung jawab sosial, tanpa kepentingan pribadi. Omoto mendefinisikan kegiatan volunteering sebagai keterlibatan seseorang dalam sebuah aktivitas yang dipilih secara bebas dan diniatkan sebagai aktivitas menolong orang lain ${ }^{33}$. Motif yang mendasari seseorang mengikuti kegiatan volunteering diantaranya adalah memberikan sesuatu yang berharga kepada masyarakat dan melayani komunitas ${ }^{34}$.

Pesantren merupakan sebagai suatu lembaga pendidikan Islam. Pesantren dari sudut historis kultural dapat dikatakan sebagai "training center" yang otomatis menjadi "cultural central" Islam yang disahkan atau dilembagakan oleh masyarakat, atau suatu perkumpulan setidaknya oleh masyarakat Islam sendiri yang secara de facto tidak dapat diabaikan oleh pemerintah $^{35}$. Pesantren memiliki model-model pengajaran yang bersifat non klasikal, yaitu model sistem pendidikan dengan metode pengajaran wetonan, yaitu metode yang di dalamnya terdapat seorang kiai yang membaca kitab dalam waktu tertentu, sedangkan santrinya membawa kitab yang sama, lalu santri mendengarkan dan menyimak bacaan kiai dan sorogan, yaitu santri yang cukup pandai mengajukan sebuah kitab kepada kiai untuk dibaca di hadapannya, kesalahan dalam membaca itu berawal dari bentuk pengajian yang sangat sederhana, pada akhirnya pesantren berkembang menjadi lembaga pendidikan secara reguler dan banyak diminati oleh masyarakat, dalam pengertian memberi pelajaran secara material maupun inmaterial, yakni mengajarkan bacaan kitab-kitab yang ditulis oleh ulama-ulama abad pertengahan dalam wujud kitab kuning pendidikan dalam arti inmaterial cenderung berbentuk suatu upaya perubahan sikap santri, agar santri menjadi pribadi yang tangguh dalam kehidupan sehari-hari. Atau dengan kata lain mengantarkan anak didik menjadi dewasa secara psikologis. $^{36}$

Pondok pesantren sebagai lembaga pendidikan yang mempunyai tujuan yang tidak jauh berbeda dengan pendidikan agama Islam yakni mencapai akhlak yang sempurna atau mendidik budi pekerti dan jiwa. Fungsi dan peran pondok pesantren sebagai penyiaran agama (lembaga dakwah) terlihat dari elemen pondok pesantren itu sendiri yakni masjid pesantren, yang dalam operasionalnya juga berfungsi sebagai masjid umum, yaitu sebagai tempat belajar agama dan ibadah masyarakat umum. Pondok pesantren sering dipakai masyarakat umum untuk menyelenggarakan majelis taklim, diskusi-diskusi keagamaan dan lain sebagainya ${ }^{37}$.

Selain itu, juga terdapat potensi-potensi dan sumber lain di pondok pesantren di antaranya yaitu:

1. Kemandirian

Dalam pembentukkan konsep berpikir serta pola pendidikan yang utama didalam pondok pesantren, tidak menggantungkan diri sendiri kepada orang lain, belajar mencukupi

\footnotetext{
${ }^{32}$ Clary, E. Gil, and Mark Snyder. "The motivations to volunteer: Theoretical and practical considerations." Current directions in psychological science 8, no. 5 (1999): 156-159.

${ }^{33}$ Omoto, Allen M., and Mark Snyder. "Sustained helping without obligation: motivation, longevity of service, and perceived attitude changes among AIDS volunteers." Journal of personality and social psychology 68, no. 4 (1995): 671.

${ }^{34}$ Pauline, Gina, and Jeffrey S. Pauline. "Volunteer motivation and demographic influences at a professional tennis event." Team performance management: an international journal 15, no. 3/4 (2009): 172184.

97.

${ }^{35}$ Djamaluddin \& Abdullah Aly, Kapita Selekta Pendidikan Islam (Bandung: Pustaka Setia, 1998). hlm.

${ }^{36}$ Bahri Ghazali, Pesantren Berwawasan Lingkungan (Jakarta: Prasasti,2003) hlm. 37

${ }^{37}$ Mastuhu, Dinamika Sistem Pendidikan Pesantren (Jakarta: INIS, 1994)
} 
atau menolong diri sendiri. Para santri yang terdidik dapat menolong diri sendiri serta menghadapi masa depan dengan penuh harapan, jalan hidup terbentang luas di depan mereka. Sebaliknya, para santri yang tidak memiliki kepercayaan pada dirinya sendiri, dia senantiasa akan mengalami berbagai hambatan karena selalu dihantui oleh keraguan, serta tidak akan mendapat kepercayaan dari masyarakat, serta hilangnya kepercayaan diri dalam menjalani setiap interaksi sosial yang ada.

2. Kebebasan

Dalam setiap diri santri diberi kebebasan untuk memilih jalan hidup kelak di tengah masyarakat. Mereka dapat dengan bebas menentukan masa depannya dengan berbekal jiwa yang besar dan optimisme yang mereka dapatkan selama ditempa dipondok pesantren selama hal itu masih dianggap sejalan dengan nilai-nilai pendidikan yang mereka dapatkan di pondok pesantren $^{38}$.

3. Ikhlas

Dalam kehidupan di pondok pesantren selalu dijiwai oleh suasana keikhlasan, yang merupakan salah satu ciri khas di Pondok pesantren. Ikhlas merupakan sesuatu yang bersifat intrinsik dan esensial bagi para nabi dan pewaris para nabi yang merupakan sumber kekuatan mereka. Ikhlas dapat ditafsirkan dengan kejujuran, ketulusan dan kemurnian. Seseorang yang berhati ikhlas dalam beramal dan beribadah maka ia akan memiliki kemurnian niat, keterusterangan dalam pikiran, tidak mencari pamrih duniawi dalam hubungannya dengan Allah dan taat dalam pengabdian-Nya ${ }^{39}$.

\section{Pejuang}

Dalam peran pondok pesantren guna mengusir penjajahtak perlu banyak diuraikanlagi. Pada zaman Belanda, dengan dilandasi iman dan demi menegakkan kebenaran dan keadilan, warga pesantren bangkit mengangkat senjata untuk menentang penjajah. Para kiai dan santrisantrinya keluar untuk melawan belanda. maka sejarah mengukir dengan tinta emas, para pahlawan nasional dari kalangan pesantren. Begitu pula pada masa pendudukan Jepang. Kembali pesantren menjadi saksi atas heroisme kiai dan santrinya dalam melancarkan pemberontakkan mengusir jepang. Semangat para santri yang demikian besar untuk berjuang disebabkan adanya keinginan mati syahid dalam rangka membela agama dan doktrin yang kuat dari pesantren bahwa cinta dan bela Negara termasuk bagian dari iman. Siapapun yang mengaku beriman, maka sebagai tandanya dia harus ikut berperang. Dalam kondisi mendesak, perang bahkan harus diprioritaskan dari ibadah-ibadah lain.

5. Tasamuh

Sikap atau perilaku Tasamuh merupakan salah satu potensi yang dimiliki oleh pondok pesantren dikarenakan, Pesantren merupakan sebuah miniatur masyarakat yang terdiri dari berbagai suku-suku, adat istiadat dan budaya yang mereka semua berkumpul dalam sebuah pesantren, para santri tidak hanya berasal dari daerah tertentu saja, melainkan berasal dari berbagai daerah bahkan ada pula dari berbagai bangsa. Pondok pesantren adalah sebuah sistem yang unik, bukan hanya dalam pendekatan pembelajarannya tapi juga pandangan hidup dan tata nilai yang dianut masing-masing pondok pesantren mempunyai keistimawan tersendiri.

Secara garis besar pondok pesantren dapat dikategorikan dalam tiga kategori, yaitu: Pondok Pesantren Salafiyah, Pondok Pesantren Khalafiyah, dan Pondok Pesantren campuran. Pondok pesantren salaf artinya lama, dahulu, atau tradisional. Pondok pesantren salafiyah adalah pondok pesantren yang melaksanakan proses pembelajaran yang menggunakan pendekatan tradisional, dan telah berlangsung sejak awal perkembangannya. Pada setiap

${ }^{38}$ Abd. Halim Soebahar, Kebijakan Pendidikan Islam: Dari Ordonasi Guru sampai UU Sisdiknas (Jakarta: Rajawali Press, 2013)

${ }^{39}$ Syamsul Ma'arif, Pesantren Inklusif Berbasis Kearifan Lokal (Yogyakarta: Kaukaba Dipantara, 2015) 
pembelajaran dilakukan secara individual atau kelompok dengan konsentrasi pada kitab kuning. Perjenjangan didasarkan pada khatamnya kitab yang dipelajari, setelah khatam santri bisa naik ke jenjang lebih tinggi dan seterusnya. Dengan selesai satu kitab tertentu maka santri dapat naik jenjang berikutnya. Pendekatan ini sejalan dengan prinsip pendidikan modern yang dikenal dengan sistem belajar tuntas.

Khalaf artinya kemudian atau belakang, sehingga Pondok pesantren khalafiyah adalah pondok pesantren yang menyelenggarakan kegiatan pendidikan dengan pendekatan modern, melalui satuan pendidikan formal, baik madrasah, maupun sekolah, atau nama lainnya, tetapi dengan pendidikan klasikal. Pembelajarannya dilakukan secara berjenjang dan berkesinambungan, dengan satuan program didasarkan pada satuan waktu, seperti catur wulan, semester dan lainnya. Pada pondok pesantren tipe ini pondok lebih banyak berfungsi sebagai asrama dan memberikan lingkungan yang kondusif untuk pendidikan agama.

Sebagian besar yang ada sekarang adalah pondok pesantren yang berada di antara rentang dua pengertian di atas. Sebagian besar pondok pesantren yang mengaku atau menamakan diri pesantren salafiyah, pada umumnya menyelenggarakan pendidikan secara klasikal dan berjenjang, walaupun tidak dengan nama madrasah atau sekolah. Demikian juga pesantren khalafiyah pada umumnya juga menyelenggarakan pendidikan dengan pendekatan pengajian kitab klasik sebagai salah satu identitas pondok pesantren. ${ }^{40}$

\section{E. Penutup}

Tradisi volunterisme di Pondok Modern Gontor 7 Putera Sulawesi Tenggara merupakan implementasi nilai-nilai panca jiwa yakni keikhlasan, kesederhanaan, kemandirian, ukhuwah diniyah/ukhuwah Islamiyah, kebebasan, dari nilai-nilai tersebut menjadi dasar dalam melaksanakan pengabdian sebagai konsekuensi atas sikap mewakafkan diri, baik dalam melaksanakan proses belajar mengajar pada santri maupun dalam pembinaan mental serta akhlak bagi setiap unsur peserta didik pada PM Gontor. Dalam meningkatkan kinerja para sukarelawan pihak pimpinan memberikan motivasi melalui pengimplementasian konsep panca jiwa sebagai rujukan utama dalam menjalankan tugas dan tanggungjawab sehingga pihak pimpinan dan pembina tidak melakukan pengawasan serta kontrol secara khusus, melainkan kepercayaan secara penuh pada para relawan akan kemandirian yang dimiliki dan evaluasi hanya dilakukan melalui hasil yang telah dicapai sesuai tujuan lembaga yang diharapkan.

\section{DAFTAR PUSTAKA}

Amin, Husnul. Corak Sosialisme Pesantren, Jurnal Pendidikan Islam Vol. X7, No.3 2012/1433.

Badarwan, Badarwan. "Perilaku Sukarela di Pesantren: Karakter Langka di tengah Pusaran Pragmatisme SDM Lembaga Pendidikan." Shautut Tarbiyah 24, no. 1 (2018): 19-36.

Tim Penyusun Kamus Pusat Bahasa. "Kamus Bahasa Indonesia." Jakarta: Pusat Bahasa (2008).

Bahri Ghazali. Pesantren Berwawasan Lingkungan (Jakarta: Prasasti, 2003)

Bungin, Burhan. Metode Penelitian Kualitatif (Jakarta: Prenada Kencana, 2004)

Clary, E. Gil, and Mark Snyder. "The motivations to volunteer: Theoretical and practical considerations." Current directions in psychological science 8, no. 5 (1999).

Djamaluddin \& Abdullah Aly. Kapita Selekta Pendidikan Islam (Bandung: Pustaka Setia, 1998)

${ }^{40}$ Tim Departemen Agama RI, Pondok Pesantren dan Madrasah Diniyah (Jakarta: Direktorat Kelembagaan Agama Islam, 2003), hlm. 30. 
Handoko, T. Hani. Manajemen, Edisi 2, Cetakan Kedelapan belas (Yogyakarta: BPFE UGM, 2003)

Husen Sanusi, Muhammad. Trimurti: Menelusuri Jejak, Sintesa, dan Genealogi berdirinya Pondok Modern Darussalam Gontor, (Etifaq Production, Bantul 2016).

Jaya, Nenet Natasudian. Meningkatkan Perilaku Ekstra Peran Karyawan (GaneC Swara, Vol. 9 No. 1 Maret 2015)

Mastuhu, Dinamika Sistem Pendidikan Pesantren (Jakarta: INIS, 1994)

Ma'arif, Syamsul. Pesantren Inklusif Berbasis Kearifan Lokal (Yogyakarta: Kaukaba Dipantara, 2015)

Miles, Matthew B. \& Huberman, A. Michael. Analisis Data Kualitatif: Buku Sumber tentang Metode-Metode Baru, Penerjemah: Tjetjep Rohendi Rohidi, Cetakan Pertama (Jakarta: UI Press, 1992)

Omoto, Allen M., and Mark Snyder. "Sustained helping without obligation: motivation, longevity of service, and perceived attitude changes among AIDS volunteers." Journal of personality and social psychology 68, no. 4 (1995).

Pauline, Gina, and Jeffrey S. Pauline. "Volunteer motivation and demographic influences at a professional tennis event." Team performance management: an international journal 15, no. 3/4 (2009).

Robbins, Stephen P. Organization Theory: Structures, Designs, And Applications, 3/e. Pearson Education India, 1990.

Robbins, Stephen P., and Timothy A. Judge. Organizational behaviour. Pearson Education Limited, 2013.

Schein, Edgar H. Organizational culture and leadership. Vol. 2. John Wiley \& Sons, 2010.

Sidhiq, Ngarifin. Humanisme Pendidikan Pesantren, AL-QALAM 11, no. 2 (2016)

Soebahar, Abd. Halim. Kebijakan Pendidikan Islam: Dari Ordonasi Guru sampai UU Sisdiknas (Jakarta: Rajawali Press, 2013)

Sugiono. Memahami Penelitian Kualitatif (Bandung: Alfabeta, 2003)

Syahrul, Syahrul. "Strategi Pengembangan Lembaga Pendidikan: Menggali Spirit PM Gontor 7 Putera, Sulawesi Tenggara." Shautut Tarbiyah 24, no. 2 (2018).

Tim Departemen agama RI. Pondok Pesantren dan Madrasah Diniyah (Jakarta: Direktorat Kelembagaan Agama Islam, 2003)

WARDUN: Warta Dunia Pondok Modern Darussalam Gontor Volume 68, Sya'ban 1436 H

Waspodo, Agung AWS, and Lussy Minadaniati. "Pengaruh Kepuasan Kerja dan Iklim Organisasi Terhadap Organizational Citizenship Behavior (OCB) Karyawan pada PT. Trubus Swadaya Depok." JRMSI-Jurnal Riset Manajemen Sains Indonesia 3, no. 1 (2012).

Wibowo, S. E., and M. Phil. Manajemen Kinerja (Jakarta: Raja Grafindo Persada, 2007). 